University of Nebraska - Lincoln

DigitalCommons@University of Nebraska - Lincoln

USDA National Wildlife Research Center - Staff Publications
U.S. Department of Agriculture: Animal and Plant Health Inspection Service

July 2002

\title{
Potential hazards of DRC- 1339 treated rice to non-target birds when used at roost staging areas in Louisiana to reduce local populations of depredating blackbirds
}

\author{
John L. Cummings \\ National Wildlife Research Center \\ James F. Glahn \\ National Wildlife Research Center \\ E. Allen Wilson \\ USDA/APHIS/WS \\ James E. Davis Jr. \\ National Wildlife Research Center
}

Follow this and additional works at: https://digitalcommons.unl.edu/icwdm_usdanwrc

Part of the Environmental Sciences Commons

Cummings, John L.; Glahn, James F.; Wilson, E. Allen; and Davis, James E. Jr., "Potential hazards of DRC1339 treated rice to non-target birds when used at roost staging areas in Louisiana to reduce local populations of depredating blackbirds" (2002). USDA National Wildlife Research Center - Staff Publications. 473.

https://digitalcommons.unl.edu/icwdm_usdanwrc/473

This Article is brought to you for free and open access by the U.S. Department of Agriculture: Animal and Plant Health Inspection Service at DigitalCommons@University of Nebraska - Lincoln. It has been accepted for inclusion in USDA National Wildlife Research Center - Staff Publications by an authorized administrator of DigitalCommons@University of Nebraska - Lincoln. 
INTERNATIONAL

\title{
Potential hazards of DRC-1339 treated rice to non-target birds when used at roost staging areas in Louisiana to reduce local populations of depredating blackbirds
}

\author{
John L. Cummings ${ }^{\mathrm{a}, *}$, James F. Glahn ${ }^{\mathrm{b}}$, E. Allen Wilson ${ }^{\mathrm{c}}$, James E. Davis Jr ${ }^{\mathrm{a}}$ \\ "National Wildife Research Center. 4lol LaPorte Areme. Fort Collins. CO 80524. USA

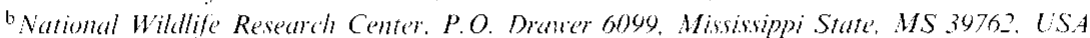 \\ 'USDA APHIS W'S. P.O. BOX 494. Crowl'? LA 70527. USA
}

\begin{abstract}
Hazards of DRC-1339 treated brown rice to non-target birds were assessed during an operational baiting program near Point Blue, Louisiana, USA. The predominant non-target birds using DRC-1339 bait sites and surrounding habitat were savannah sparrows ( $P$ asser(uhlss sandwichensis), mourning doves (Zenaida macroura), killdeers (Charadrius vociferus), and unidentified sparrows (Fringillidae). Systematic searches of DRC-1339 bait sites and adjacent habitat for non-target dead or affected birds produced 1 northern cardinal (Cardinalis curdinalis). There was no mortality of potential non-target species, savannah sparrows, white-crown sparrows (Zonotrichia leucophris), field sparrows (Spizella pusilla), song sparrow (Melospiza melodia) and chipping sparrows (Spizella passerina) that were held in captivity and offered only 2\% DRC-1339 treated brown rice diluted 1:27 with untreated brown rice for 1 and $12 \mathrm{~h}$ each day for 5 days. There was no hazard of DRC-1339 to most non-target species using the test areas. Published by Elsevier Science Ltd.
\end{abstract}

\section{Introduction}

Several species of blackbirds, particularly red-winged blackbirds (Agelaius phoeniceus) congregating in large spring roosts, cause extensive damage to newly planted rice. Losses to rice growers have been estimated at $\$ 11.5$ million US (Besser, 1985). Damage is not uniformly distributed, but rather localized and proportional to the size of the nearby bird roosts. In Louisiana, damage to newly planted rice can be locally severe especially where fields are planted adjacent to blackbird roosting habitat (Wilson, 1985).

Several techniques are available to rice growers for alleviating blackbird damage, such as habitat manipulation, mechanical and pyrotechnic devices, and shooting (Dolbeer et al., 1994). However, each of these techniques has limitations because of cost, logistics or effectiveness. In Louisiana, since 1989, DRC-1339 treated brown rice baiting has been used to reduce blackbird populations causing damage to rice. DRC-1339 avicide (3-chloro- $p$-toluidine hydrochloride or CPTH ) is a slow-acting toxicant that is highly toxic to most pest birds (Icterinae), but low-to-moderately toxic to raptors and to most mammalian species (Knittle et al., 1980).

\footnotetext{
* Corresponding author.
}

The primary mode of action of DRC-1339 is an irreversible necrosis of the kidney and an affected bird is subsequently unable to excrete uric acid. Death occurs from uremia 24-72 $\mathrm{h}$ after ingestion of a lethal dose (Palmore, 1978; Cunningham et al., 1979).

The use of DRC-1339 treated brown rice in Louisiana is restricted to a period between February 15 and March 15 and to blackbird staging areas that include stubble fields, bare-ground non-crop areas and open grass sites. Several non-target birds have been observed foraging on DRC-1339 bait sites with no or few reported mortalities because of the mode of action of the chemical (Knittle et al., 1980; Glahn et al., 1990; Cummings et al., 1992). However, estimating avian mortality caused by DRC-1339 is difficult, and failure to find affected or dead non-target birds does not rule out the potential hazard. Success of locating small bird carcasses on bait sites or in adjacent habitat can range from $30 \%$ to $88 \%$ (Linz et al., 1991; Tobin and Dolbeer, 1990). Federal, state and private groups have voiced concerns that DRC-1339 maybe hazardous to non-target birds that use bait sites. This study identified non-target birds that use DRC-1339 bait sites in Louisiana and examined the toxicity of DRC-1339 to selected species. 


\section{Methods}

\subsection{Test site}

The study was conducted near Point Blue, LA, in association with a DRC-1339 operational baiting program (USDA Wildlife Services) to reduce blackbird damage to rice. $\mathrm{DRC}-1339$ baits sites $(n=14)$ ranged in size from 0.8 to 2.5 ha and consisted of fallow fields, stubble ficlds and pastures where livestock were cxcluded. Baiting sites were strategically located within $3.6 \mathrm{~km}$ of a 5.4 million blackbird roost. Each site was pre-baited for 3-4 days with untreated brown rice. Of the 14 bait sites used by blackbirds, 8 were selected for study because of limited man-power and for logistical reasons. Following this period, 2\% DRC-1339 treated brown rice diluted 1:27 was applied to the site. All rice was broadcast with ground equipment calibrated to deliver $56-112 \mathrm{~kg} / \mathrm{ha}$ in swaths of $17 \mathrm{~m}$ wide. Swaths were separated by $17 \mathrm{~m}$. The application rate for each bait site was $28-56 \mathrm{~kg} / \mathrm{ha}$.

\subsection{Non-target use}

Non-target birds using DRC-1339 bait sites were counted daily starting 4 days before DRC-1339 baiting and continuing for up to 13 days post-treatment. DRC-1339 bait sites were observed each day in $1 \mathrm{~h}$ blocks for a total of $4 \mathrm{~h} /$ day between sunrise and $1000 \mathrm{~h}, 1000$ and $1200 \mathrm{~h}, 1200$ and $1500 \mathrm{~h}$, and $1500 \mathrm{~h}$ and sunset. The number and species of non-target birds using each site were recorded. The starting times and observation location remained the same throughout the test.

\subsection{Dietary feeding test}

Two groups of non-target birds ( $n=41,30)$ were captured with mist nets on separate days at and around DRC-1339 bait sites prior to treatment. Birds were housed by species in $2 \times 4 \times 5 \mathrm{~m}$ test pens with free access to brown rice and water. After 13 days in captivity, group 1:35 savannah sparrows, 3 song sparrows and 3 chipping sparrows was assigned the following treatment: $2 \%$ DRC-1339 treated brown rice diluted $1: 27$ with untreated brown rice was offered for a $1 \mathrm{~h}$ period each day for five days. Group 2: 19 savannah sparrows, 8 white-crowned sparrows and 3 field sparrows was assigned the following treatment: $2 \%$ DRC-1339 treated brown rice diluted 1:27 with untreated brown rice was offered for a 12-h period each day for 5 days. Each day at 0645, each species group was presented with a plastic pan containing $500 \mathrm{~g}$ of $2 \%$ DRC-1339 treated brown rice diluted $1: 27$ with untreated brown rice. At the end of each exposure period, $1 \mathrm{~h}$ or $12 \mathrm{~h}$, plastic pans were removed and consumption was recorded by weighing the remaining treated rice. Birds were only offered the test food during the 5-day test period. Birds were monitored 3 days beyond the conclusion

\section{DRC-1339 Bait Sites}

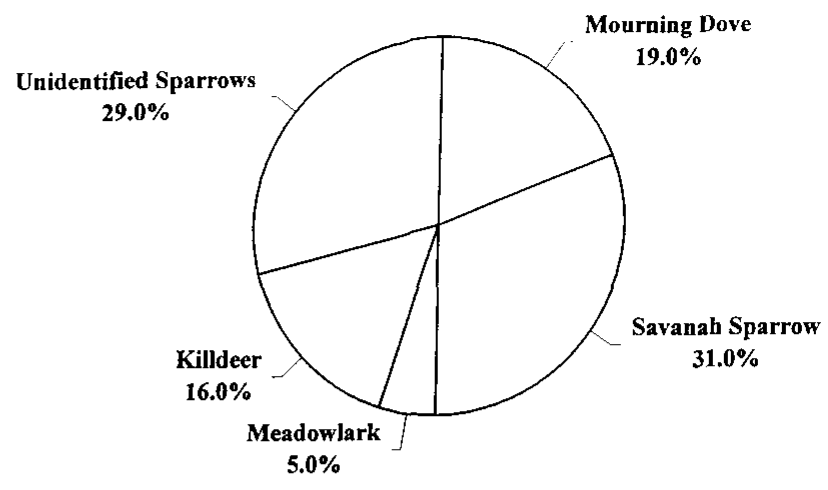

Surrounding Habitat

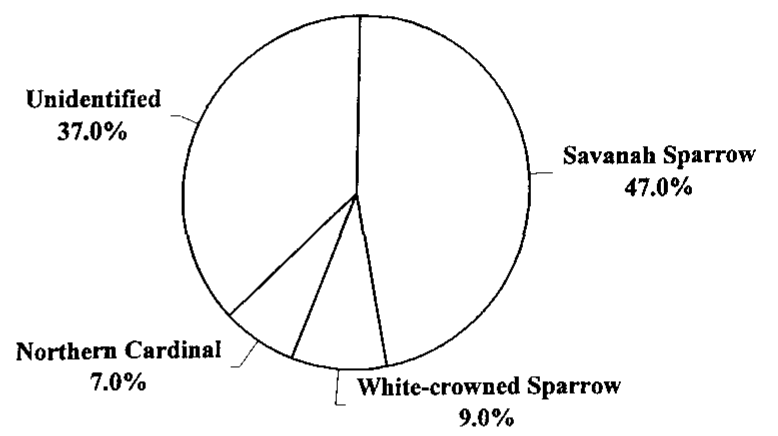

Fig. 1. Non-target bird use of DRC -1339 bait sites and surrounding habitat.

of the test for any signs of DRC-1339 poisoning (DeCino et al., 1966).

\subsection{Non-target bird searches}

On each DRC-1339 bait site $(n=8)$ a carcass search was conducted by a searcher systematically walking the entire site every 2 days between 0900 and 1200 starting 4 days before DRC-1339 baiting and continuing to the conclusion of the test. In addition, a $6 \times 300 \mathrm{~m}$ transect of non-target habit adjacent to the each bait site was searched daily during the same period. Non-target birds found sick or dead were collected and examined grossly for pathological signs of DRC-1339 poisoning (DeCino et al., 1966).

\section{Results}

\subsection{Non-target use}

The predominant non-target birds using DRC-1339 bait sites and surrounding habitat were savannah sparrows, mourning doves, killdeer, and unidentified sparrows (Fringillidae; Fig. 1). The average number of non-target birds observed daily using the DRC-1339 bait sites and 
surrounding habitat areas were $48(\mathrm{SE}=12)$ and 141 $(\mathrm{SE}=42)$, respectively.

\subsection{Dietary feeding test}

There was no mortality of non-target birds in either treatment group from consuming 2\% DRC-1339 treated brown rice diluted 1:27 with untreated brown rice. The average daily consumption of DRC-1339 treated brown rice diluted $1: 27$ with untreated brown rice for savannah sparrows, white-crowned sparrows, chipping sparrows, field sparrows and song sparrows was $1.4,2.2,1.6,0.9$ and $1.3 \mathrm{~g}$, respectively.

\subsection{Non-target bird searches}

Ninety-four searches of DRC-1339 bait sites and surrounding habitat produced 1 northern male cardinal. This bird showed pathological signs of DRC-1339 poisoning.

\section{Discussion}

Numerous non-target birds used DRC-1339 bait sites but the numbers of species involved were low. Several species of sparrows, and only three other bird species were observed with any degree of regularity on DRC-1339 bait sites. The low numbers of species may have been related to such factors as the location of bait sites, feeding activity of blackbirds, or bait availability. Our bird observations were similar to that of Glahn et al. (1990) which indicated that blackbirds can overwhelm DRC-1339 bait sites and exclude non-target bird use, and that most DRC-1339 baits were consumed by target birds each day.

The dietary feeding test was designed to test worst case scenarios for exposure of non-target birds to DRC-1339 treated brown rice for 5 days. The results for the sparrow species were similar to those of laboratory avian acute LD50 tests on house sparrows (Passer domesticus) and white-crowned sparrows where birds did not die even at DRC- 1339 doses $>320 \mathrm{mg} / \mathrm{kg}$ (Schafer Jr., 1979). Consumption of DRC-1339 treated brown rice diluted $1: 27$ with untreated brown rice by savannah sparrows was similar to other daily consumption rates, $1.1 \mathrm{~g}$ /day (Cummings, J. 2001 unpubl. data). However, mourning doves, meadow larks (Stumella magna) and killdeers may be more susceptible to DRC-1339 treated brown rice because of low $L_{50}$ 's and should be examined in dietary feeding tests.

Searches of DRC-1339 bait sites and surrounding habitats indicated that DRC-1339 treated brown rice did not cause mortality to non-target birds. However, provided the time spans between search periods, the scavenger guilds which include mink (Mustela rison), raccoon (Procyon lotor), striped skunk (Melhitis mephitis) and opossum (Didelphis (irginianus) in the test areas, and searchers' efficiency, the number of non-target sick or dead birds could have been underestimated. Scarchers efficiency is an important aspect of any hazard study. In this study, searchers were only able to find about $20 \%$ of the dead savannah sparrows placed at random on bait swaths $17 \mathrm{~m}$ wide in fallow fields moving at about $2 \mathrm{~km} / \mathrm{h}$. The low efficiency rate indicates that some non-target birds could have been overlooked. In other studies, searchers found $80 \%$ of the rock doves (Columba litia) and $30 \%$ of the house sparrows (James and Haak, 1970), 64-88\% of female red-winged blackbirds (Linz et al., 1991), and $36 \%$ of starlings (Sturnus vulgaris, Witmer et al., 1995). They cite morphological characteristics, habitat type and searcher experience as important factors affecting success. The low recovery rate of non-targets in our study could be attributed to these factors; however, the dictary test results indicate that little or no hazard of DRC-1339 may exist for most non-target species using the test areas.

\section{Acknowledgements}

We thank John Maestrelli, Dwight LeBlanc, and Joe Musick for assistance in the field and Larry Clark, Mark Tobin and Edward Schafer for review of the manuscript. We followed the criteria established by the Animal Welfare Act and the National Wildlife Research Center Animal Care and Use Committee during this study.

\section{References}

Besser, J.F., 1985. A growers guide to reducing bird damage to US agriculture crops. National Wildlife Research Control Report 340 , 90pp., unpublished.

Cummings, J.L., Glahn, J.E., Wilson, E.A., Davis Jr., J.E., Bergman, D.L., Harper, G.A., 1992. Efficacy and non-target hazards of DRC-1339 treated rice baits used to reduce roosting populations of depredating blackbirds in Louisiana. National Wildlife Research Control Report 481, 136pp.

Cunningham, D.J., Schafer Jr., E.W.. McConnell, L.K., 1979. DRC-1339 and DRC -2698 residues in starlings: preliminary evaluation of their secondary hazard potential. Proceedings of the Bird Control Seminat $8,31-37$.

DeCino, T.J., Cunningham, D.J., Schafer Jr., E.W., 1966. Toxicity of DRC-1339 to starlings. Joumal of Wildlife Management 30, 249253.

Dolbeer, R.A., Holler, N.A., Hawthorne, D.W., 1994. Identification and control of wildlife damage. In: Bookhout, T.A. (Ed.), Research and Management Techniques for Wildlife and Habitats. The Wildlife Society, Bethesda, Md, pp. 474-506.

Glahn, J.F., Wilson. E.A., Avery. M.L.. 1990. Evaluation of a DRC-1339 baiting program to reduce sprouting rice damage caused by spring roosting blackbirds. National Wildlife Research Control Report 448 , $25 \mathrm{pp}$. unpublished.

James, B.W., Haak, B.A., 1970. Factors affecting avian flight behavior and collision mortality at transmission lines, Bonneville Power Adminstration, Portland, OR, $109 \mathrm{pp}$.

Knittle, C.E., Guarino, J.L., Nelson, J.C., DeHaven, R.W., Twedt. D.J., 1980. Baiting blackbirds and starling congregating areas in Kentucky and Tennessee. Proceedings of the Vertebrate Pest Conference 9. 31-37.

Linz. G.M., Davis Jr.. J.E.. Engeman, R.M.. Otis. D.L.. Avery, M.L.. 1991. Estimating survival of bird carcasses in cattail marshes. Wildlife Society Bulletin 19, 195-199. 
Palmore, W.P.. 1978. Diagnosis of toxic acute renal failure in cats. Journal of Florida Veterinarian 14-15, 36-37.

Tobin, M.E., Dolbeer, R.A.. 1990. Disappearance and recoverability of songbird carcasses in fruit orchards. Journal of Wildlife Management $61,237-242$.

Schafer Jr., E.W.. 1979. Physical. chemical and biological properties of CPT. CPTH, CAT. CPT-C, and CPT-D. National Wildlife Research Control Report 121, $81 \mathrm{pp}$.
Wilson. E.A.. 1985. Blackbird depredation on rice in southwestern Louisiana. Thesis. Louisiana State University, Baton Rouge, 91pp.

Witmer, G.W.. Pipas. M.J.. Campbell. D.L., 1995. Effectiveness of search patterns for recovery of animal carcasses in relation to pocket gopher infestation control. International Biodeterioration \& Biodegradation 42. $177-187$. 